\title{
KECEMASAN MATEMATIKA DAN PEMAHAMAN MATEMATIS
}

\author{
RISMA NURUL AULIYA \\ rismauliya@gmail.com \\ Program Studi Teknik Informatika, Fakultas Teknik, Matematika, dan IPA \\ Universitas Indraprasta PGRI
}

\begin{abstract}
Abstrak. Penelitian ini bertujuan untuk mengkaji pengaruh kecemasan matematika terhadap kecemasan matematika peserta didik. Hipotesis penelitian ini adalah kecemasan matematika berpengaruh signifikan terhadap kemampuan pemahaman matematis. Metode yang digunakan dalam penelitian adalah metode survei. Populasinya, yaitu seluruh peserta didik kelas VIII di salah satu SMP Negeri Jakarta Selatan. Adapun, sampelnya terdiri dari 66 peserta didik yang dipilih menggunakan teknik purposive sampling. Instrumen yang digunakan adalah angket kecemasan matematika yang terdiri dari 28 pernyataan, meliputi aspek somatik, kognitif, sikap, dan pemahaman matematis. Kecemasan matematika ketika belajar matematika secara berkelompok terdiri dari 12 pernyataan dan kecemasan matematika ketika mengerjakan tes matematika terdiri dari 16 pernyataan. Analisis data menggunakan analisis regresi linear sederhana. Hasil penelitian menunjukkan bahwa terdapat kecemasan matematika berpengaruh signifikan terhadap kemampuan pemahaman matematis peserta didik.
\end{abstract}

Kata kunci: kemampuan pemahaman matematis, kecemasan, matematika

\begin{abstract}
The aims of this research are intended to examine the effect of mathematics anxiety toward junior high school students' mathematical understanding ability. The hypothesis of this research was mathematics anxiety had significant effect toward students' mathematical understanding ability. The research utilized a survey method. The population in this research were students of grade eight from one junior high school in South Jakarta. As concern, the sample comprised of 66 students who selected by purposive sampling technique. The instrument comprised Mathematics Anxiety Questionnaire. The items were grouped under four sub-headings of attitudinal, cognitive, somatic, and mathematical knowledge/understanding. Two forms of questionnaire were designed. One sought information on anxiety when working on mathematics in a class consist of 12 items and the other on anxiety on completing a test on mathematics, consist of 16 items. The data analysis used simple linear regression analysis. The result showed that mathematics anxiety had significant effect toward students' mathematical understanding ability.
\end{abstract}

Keywords: mathematical understanding ability, anxiety, mathematics

\section{PENDAHULUAN}

Matematika yang diberikan di sekolah sangat penting dalam upaya meningkatkan sumber daya manusia yang berkualitas. Menyadari pentingnya pembelajaran matematika di sekolah, dalam Undang-undang RI No. 20 Tahun 2003 tentang Sisdiknas (Sistem Pendidikan Nasional) Pasal 37 ditegaskan bahwa mata pelajaran matematika merupakan salah satu mata pelajaran wajib bagi siswa pada jenjang pendidikan dasar dan menengah.

Pentingnya orang belajar matematika, tidak terlepas dari perannya dalam berbagai kehidupan, misalnya berbagai informasi dan gagasan banyak dikomunikasikan atau disampaikan dengan bahasa matematika, serta banyak masalah yang dapat disajikan 
ke dalam model matematika. Selain itu, dengan mempelajari matematika, seseorang terbiasa berpikir secara sistematis, ilmiah, menggunakan logika, kritis, serta dapat meningkatkan daya kreativitasnya. Tujuan pembelajaran matematika di sekolah menurut kurikulum KTSP (BSNP, 2006), antara lain:

1. Memahami konsep matematika, menjelaskan keterkaitan antarkonsep dan mengaplikasikan konsep secara luwes, akurat, efisien, dan tepat dalam pemecahan masalah.

2. Menggunakan penalaran pada pola dan sifat, melakukan manipulasi matematika dalam membuat generalisasi, menyusun bukti, atau menjelaskan gagasan dan pernyataan matematika.

3. Memecahkan masalah yang meliputi memahami masalah, merancang model matematik, menyelesaikan model, dan menafsirkan solusi.

4. Mengkomunikasikan gagasan dengan simbol, tabel, diagram, atau media lain untuk memperjelas keadaan atau masalah.

5. Memiliki sikap menghargai kegunaan matematika dalam kehidupan, sikap rasa ingin tahu, perhatian, dan minat dalam mempelajari matematika, serta sikap ulet dan percaya diri dalam pemecahan.

Pemahaman terhadap konsep matematis merupakan salah satu dari tujuan pembelajaran matematika di sekolah. Selain itu, NCTM (2000) menyatakan bahwa visi dari matematika sekolah adalah berdasarkan pada pembelajaran matematika peserta didik yang disertai dengan pemahaman. Bransford, Brown, dan Cocking (NCTM, 2000) memaparkan belajar matematika dengan disertai pemahaman juga merupakan komponen terpenting dari kemampuan, bersama dengan kecakapan pengetahuan faktual dan prosedural. Belajar matematika dengan disertai pemahaman sangat diperlukan untuk memungkinkan peserta didik menyelesaikan masalah lain yang akan mereka hadapi di masa yang akan datang (NCTM, 2000).

Namun, pentingnya pemahaman yang telah dijelaskan sebelumnya tidak sejalan dengan kemampuan pemahaman matematis yang telah dicapai peserta didik saat ini dan hal ini terlihat dari hasil survei kemampuan yang dilakukan oleh Programme for International Student Assessment (PISA) pada tahun 2009 dan The Trends in International Mathematics and Science Study (TIMSS) pada tahun 2011. TIMSS dan PISA merupakan dua lembaga dunia yang menyelenggarakan tes yang salah satunya ditujukan untuk pelajar setingkat SMP yang telah dipilih secara acak dari tiap negara. PISA 2009 diikuti oleh 65 negara dan TIMSS 2011 diikuti oleh 45 negara.

Hasil PISA 2009 menunjukkan bahwa skor rata-rata matematika siswa Indonesia adalah 371, dengan rata-rata skor internasional sebesar 496. PISA bertujuan untuk mengukur kemampuan matematis, yang didefinisikan sebagai kemampuan peserta didik untuk merumuskan, menggunakan dan menginterpretasikan matematika dalam berbagai konteks matematika, yaitu meliputi penalaran secara matematis dan penggunaan konsep matematis, prosedur, fakta, alat untuk menggambarkan, menjelaskan, dan memprediksi fenomena (Cheung, 2012). Hasil TIMSS 2011 menyebutkan bahwa skor rata-rata matematika peserta didik di Indonesia adalah 386, dengan rata-rata skor internasional adalah 500. Salah satu dari standar internasional TIMSS 2011 mengenai prestasi matematika, yaitu peserta didik dapat mengaplikasikan pemahaman dan pengetahuan mereka dalam berbagai situasi yang kompleks (Mullis, Martin, Foy, dan Arora, 2012).

Salah satu faktor penyebab dari rendahnya kemampuan pemahaman matematis peserta didik di Indonesia adalah pandangan negatif peserta didik terhadap matematika. Matematika dianggap sebagai pelajaran yang sulit, karena karakteristik matematika yang bersifat abstrak, logis, sistematis dan penuh dengan lambang serta rumus yang membingungkan. Sejalan dengan pendapat yang dikemukakan oleh Yusof dan Tall 
(Nurhanurawati dan Sutiarso, 2008), yaitu sikap negatif terhadap matematika biasanya muncul ketika peserta didik mengalami kesulitan dalam menyelesaikan soal atau ketika ujian, jika kondisi ini terjadi secara berulang-ulang maka sikap negatif tersebut akan berubah menjadi kecemasan matematika.

Kecemasan matematika mungkin mengalami puncaknya ketika ujian nasional (Rupilu, 2012). Hal ini disebabkan oleh banyaknya rumus matematika yang harus diingat, dan peserta didik khawatir ketika sampai di dalam kelas nanti soal-soal yang keluar justru berasal dari rumus yang lupa diingat (Alamijaya, 2012). Kondisi ini dapat menyebabkan peserta didik tidak dapat mengerjakan soal-soal ujian matematika tersebut, bahkan dapat menyebabkan peserta didik tidak lulus ujian. Sebagai bukti, pada UN 2012 tingkat SMP ada 15.945 peserta didik yang dinyatakan tidak lulus, dan 1.330 di antaranya tidak lulus karena tersandung ujian matematika (Badudu, 2012).

Kecemasan matematika merupakan salah satu hambatan yang sangat serius dalam pendidikan, serta berkembang pada anak-anak dan remaja ketika mereka dalam lingkungan sekolah (Warren Jr, Rambow, Pascarella, Michel, Schultz, dan Marcus, 2005). Luo, Wang, dan Luo (2009) berpendapat bahwa kecemasan matematika merupakan sejenis penyakit. Secara khusus, kecemasan matematika mengacu pada reaksi suasana hati yang tidak sehat, yang terjadi ketika seseorang menghadapi persoalan matematika. yang menunjukkan mereka panik dan kehilangan akal, depresi, pasrah, gelisah, takut, dan disertai dengan beberapa reaksi psikologi, seperti berkeringat pada wajahnya, mengepalkan tangan, sakit, muntah, bibir kering, dan pucat (Luo, Wang, dan Luo, 2009).

Beberapa hasil penelitian menyatakan bahwa kecemasan matematika merupakan salah satu faktor yang memiliki hubungan negatif dengan prestasi belajar. Clute dan Hembree (Vahedi dan Farrokhi, 2011) menemukan bahwa peserta didik yang memiliki tingkat kecemasan matematika yang tinggi memiliki prestasi belajar matematika yang rendah. Hasil penelitian Daneshamooz, Alamolhodaei, dan Darvishian (2012) juga menunjukkan bahwa kecemasan matematika berkorelasi negatif dengan kinerja matematika. Sejalan dengan itu, Hellum-Alexander (2010) dalam penelitiannya menemukan bahwa kecemasan matematika juga berpengaruh terhadap kemampuan matematis dan termasuk di dalamnya adalah kemampuan pemahaman matematis.

Arem (Zakaria, Zain, Ahmad, dan Erlina, 2012) menyatakan bahwa peserta didik dengan kecemasan matematika yang tinggi cenderung kurang percaya diri dalam memahami konsep matematis. Hasil penelitian Zakaria, Zain, Ahmad, dan Erlina (2012) juga menunjukkan bahwa peserta didik yang berprestasi memiliki tingkat kecemasan matematika yang rendah, sedangkan peserta didik yang kurang berprestasi memiliki kecemasan matematika yang tinggi. Hal ini dikarenakan peserta didik yang berprestasi memiliki pemahaman matematis dan kepercayaan diri yang lebih baik dibandingkan peserta didik yang kurang berprestasi. Berdasarkan latar belakang yang telah diuraikan, peneliti tertarik untuk melakukan penelitian tentang pengaruh kecemasan matematika terhadap kemampuan pemahaman matematis peserta didik.

\section{TINJAUAN PUSTAKA}

\section{Pemahaman Matematis}

Gardner (Hiebert dan Carpenter, 1992) menyatakan bahwa pemahaman adalah salah satu aspek dasar dalam pembelajaran, sehingga model pembelajaran yang digunakan harus memperhatikan persoalan mengenai pemahaman. Bloom (Ruseffendi, 1991) menyatakan bahwa terdapat tiga jenis pemahaman:

a. Pengubahan (translation), yaitu mampu mengubah soal kata-kata ke dalam simbol dan sebaliknya. 
b. Pemberian arti (interpretation), yaitu mampu mengartikan suatu kesamaan.

c. Pembuatan ekstrapolasi (extrapolation), misalnya mampu memperkirakan suatu kecenderungan yang tersirat dalam suatu diagram.

Sementara itu, Hiebert dan Carpenter (1992) mengklasifikasikan pemahaman matematika secara dikhotomi antara pemahaman prosedural dan pemahaman konseptual. Pemahaman konseptual mendukung daya ingat, karena fakta-fakta dan metode yang dipelajari saling terkait, mereka lebih mudah untuk mengingat dan menggunakannya, serta mereka dapat mengkonstruksi ulang ketika lupa (Hiebert dan Carpenter, 1992). Pemahaman prosedural adalah pengetahuan tentang simbol untuk merepresentasikan ide matematika serta aturan dan prosedur yang digunakan untuk menyelesaikan tugas matematika (Utomo, 2010).

Sejalan dengan Hiebert dan Carpenter, Skemp (Kastberg, 2002) juga membedakan pemahaman matematika dalam dua jenis, yaitu pemahaman relasional dan pemahaman instrumental. Pemahaman relasional didefinisikan sebagai "knowing what to do and why" dan pemahaman instrumental didefinisikan sebagai "rules without reasons". Kemudian, Skemp (Kastberg, 2002) merevisi definisi mengenai kedua pemahaman tersebut dan menyertakan jenis pemahaman yang baru, yang disebut pemahaman formal, yaitu:

a. Pemahaman instrumental merupakan kemampuan untuk menerapkan aturan yang tepat pada penyelesaian dari suatu masalah, tanpa mengetahui mengapa aturan tersebut bekerja.

b. Pemahaman relasional merupakan kemampuan untuk menarik kesimpulan aturan atau prosedur tertentu dari hubungan matematis yang lebih umum.

c. Pemahaman formal merupakan kemampuan untuk menghubungkan simbol dan notasi matematis dengan ide-ide matematis yang relevan, dan mengkombinasikan ide-ide tersebut ke dalam rangkaian penalaran logis.

Kebanyakan guru lebih memilih untuk mengajarkan pemahaman instrumental, karena mereka beranggapan bahwa pembelajaran matematika yang menekankan pada pemahaman instrumental relatif lebih mudah. Berdasarkan anggapan ini, Skemp (1976) berpendapat bahwa para guru memilih untuk mengajarkan pemahaman matematis hanya pada level instrumental didasarkan pada salah satu atau beberapa alasan berikut ini:

1) Pemahaman relasional memerlukan waktu yang lebih lama untuk mencapainya.

2) Pemahaman relasional untuk topik-topik tertentu terlalu sulit.

3) Kemampuan relasional dibutuhkan untuk digunakan pada pelajaran lainnya (misalnya, sains), sebelum dapat dipahami secara relasional dengan skema yang segera tersedia pada siswa.

4) Guru matematika yang masih pemula cenderung mengajarkan matematika secara instrumental, karena guru-guru lainnya pun seperti itu.

Walaupun pemahaman relasional dinilai lebih sulit dibandingkan dengan pemahaman instrumental, tetapi memiliki beberapa keuntungan. Skemp (1976) menyatakan bahwa minimal terdapat empat keuntungan dalam pemahaman relasional, antara lain:

1) Pemahaman relasional lebih mudah diadaptasikan pada tugas atau persoalan baru.

2) Lebih mudah untuk diingat.

3) Pemahaman relasional dapat lebih efektif sebagai tujuan, berkaitan dengan nomor 4 , yaitu:

4) Skema relasional merupakan hal yang pokok dalam kualitas ilmu pengetahuan. Polya (Meel, 2003) mengidentifikasi empat tahap dalam pemahaman matematis, yaitu: 
a. Pemahaman mekanikal yang dicirikan oleh mengingat dan menerapkan rumus secara rutin dan menghitung secara sederhana.

b. Pemahaman induktif, yaitu menerapkan rumus atau konsep dalam kasus sederhana atau dalam kasus serupa.

c. Pemahaman rasional, yaitu membuktikan kebenaran suatu rumus dan teorema.

d. Pemahaman intuitif, yaitu memperkirakan kebenaran dengan pasti (tanpa ragu-ragu) sebelum menganalisis lebih lanjut.

Berdasarkan penjelasan di atas, kemampuan pemahaman matematis yang akan diteliti, yaitu pemahaman instrumental dan pemahaman relasional. Indikator pemahaman matematis yang digunakan sebagai acuan dalam penelitian ini, antara lain: (1) kemampuan menerapkan konsep secara algoritma; (2) kemampuan menyajikan konsep dalam berbagai bentuk representasi matematika; dan (3) kemampuan mengaitkan berbagai konsep.

\section{Kecemasan Matematika}

Kecemasan matematika telah menjadi fokus utama dari banyak penelitian dalam bidang psikologi dan pendidikan pada beberapa tahun yang lalu. Baloğlu (Mainey, 2004) menjelaskan bahwa para peneliti dalam bidang psikologi telah mengidentifikasi dua komponen dari kecemasan secara umum, yaitu kecemasan menurut sifat dan situasinya. Kecemasan menurut sifatnya mengacu pada kecenderungan kecemasan pada seseorang, dan kecemasan menurut situasinya merupakan suatu kondisi emosional sementara, di antaranya adalah kecemasan matematika yang dikenali sebagai situasi tertentu yang muncul dalam lingkungan matematis (Baloğlu, dalam Mainey, 2004).

Kecemasan matematika pada banyak hal mudah untuk digambarkan dan didefinisikan, yaitu merupakan perasaan cemas yang dialami oleh beberapa individu ketika menghadapi persoalan matematis (Sheffield dan Hunt, 2006). Ashcraft yang merupakan peneliti utama dalam bidang ini, menggambarkannya sebagai perasaan tegang atau takut yang diakibatkan oleh manipulasi angka biasa dan pemecahan masalah matematis. Para peserta didik mungkin merasakan detak jantung yang lebih cepat atau kuat, keyakinan bahwa mereka tidak mampu untuk menyelesaikan masalah matematis, ataupun menghindari pelajaran matematika (Sheffield dan Hunt, 2006).

Furner dan Duffy (Sun dan Pyzdrowski, 2009) menyatakan bahwa kecemasan matematika berhubungan dengan bidang afektif dan kognitif. Bidang afektif terkait pada kondisi emosi yang berhubungan dengan rasa takut dan khawatir terhadap masa depan, dan bidang kognitif berhubungan pada ketidakmampuan dalam melakukan tugas matematika tertentu.

Sementara itu, Bursal dan Paznokas (Gresham, 2010) mengatakan bahwa kecemasan matematika merupakan keadaan tidak berdaya dan panik ketika diminta untuk mengerjakan tugas matematis. Furner dan Berman (Gresham, 2010) juga menggambarkan kecemasan matematika sebagai sindrom "saya tidak bisa", kecemasan matematika dapat disebabkan dari pengalaman matematika yang memalukan atau karena ketidakmampuan dalam menerapkan pemahaman dan penggunaan konsep matematis. Peserta didik mungkin mengalami kecemasan matematika karena mereka tidak pernah mengalami keberhasilan di kelas matematika (Smith, 2004).

Hadfield dan McNeil (Erdoğan, Kesici, dan Şahin, 2011) mengklasifikasikan faktor-faktor penyebab dari kecemasan matematika, antara lain faktor lingkungan, mental dan individu. Kemudian, Lazarus, Averill, dan Fitzgerald (Erdoğan, Kesici, dan Şahin, 2011) menjelaskan faktor-faktor tersebut, yaitu sebagai berikut:

a) Faktor lingkungan, meliputi pengalaman dalam kelas matematika dan kepribadian dari guru matematika. 
b) Faktor mental, berhubungan dengan kemampuan abstraksi dan logika tingkat tinggi dalam konten matematika.

c) Faktor individu, meliputi self-esteem, kondisi fisik yang baik, sikap terhadap matematika, kepercayaan diri, gaya belajar, dan pengalaman sebelumnya yang berhubungan dengan matematika.

Ashcraft dan Faust (Zakaria dan Nordin, 2007) juga menyatakan bahwa kecemasan matematika yang tinggi akan mengakibatkan kemampuan berhitung yang rendah, pengetahuan yang kurang mengenai matematika, dan ketidakmampuan dalam menemukan strategi khusus dan hubungan dalam bidang matematika. Oleh karena itu, Freeman (2006) memberikan sepuluh kiat mengurangi kecemasan matematika bila terjadi pada peserta didik, yaitu:

1) Mengatasi kesan diri negatif terhadap matematika.

2) Mengajukan pertanyaan, artinya seorang peserta didik harus membiasakan diri untuk mengajukan pertanyaan bila mengalami kesulitan

3) Mengingat bahwa matematika adalah pengetahuan yang asing (baru), oleh karena itu peserta didik harus berani mencoba memahami matematika.

4) Jangan semata-mata mengandalkan memori sendiri dalam belajar.

5) Membaca buku teks matematika dengan baik, artinya bila seseorang peserta didik menemui masalah dalam belajar matematika maka disarankan untuk membaca ulang lagi buku teks matematika dan tidak terbatas pada satu buku teks saja.

6) Mempelajari matematika dengan menggunakan cara belajar sendiri.

7) Mencari bantuan bila menemukan materi yang tidak dipahami.

8) Menciptakan keadaan rileks dan rasa senang ketika belajar matematika.

9) Mengatakan "saya cinta matematika".

10) Mengembangkan rasa tanggung jawab bila mendapat kesuksesan dan kegagalan.

Woodard (Zakaria dan Nordin, 2007) juga menyarankan beberapa teknik yang dapat digunakan untuk mengurangi kecemasan matematika, antara lain:

1) Menciptakan lingkungan pembelajaran matematika di mana peserta tidak merasa terancam, tetapi merasa tenang dan santai.

2) Menggunakan kelompok kooperatif dapat membantu peserta didik untuk memahami masalah, karena mereka merasa bahwa teman mereka yang lainnya pun mempunyai masalah yang sama.

3) Mengajar dengan pelan, dapat membantu peserta didik memahami dengan lebih baik mengenai materi yang diajarkan.

4) Memberikan pembelajaran tambahan sehingga tidak ada peserta didik yang tertinggal secara akademis.

\section{METODE}

Penelitian ini merupakan penelitian survei dengan pendekatan kuantitatif, di mana peneliti menggambarkan fenomena yang terjadi berdasarkan data yang diambil dari responden menggunakan instrumen yang telah divalidasi sebelumnya. Desain penelitian yang digunakan adalah analisis regresi linear sederhana, untuk mengetahui pengaruh kecemasan matematika terhadap kemampuan pemahaman matematis.

Pengujian parameter regresi dilakukan untuk mengetahui tingkat keberartian penduga parameter yang dilakukan melalui pengujian hipotesis. Penelitian ini melibatkan satu variabel bebas, yaitu kecemasan matematika (X) dan satu variabel terikat, yaitu kemampuan pemahaman matematis (Y). Model matematis dari regresi linear sederhana yang akan diperoleh sebagai berikut:

dengan,

$$
\widehat{Y}=a_{0}+a_{1} X
$$


$\widehat{Y}:$ kemampuan pemahaman matematis

$a_{0}:$ konstanta

$a_{1}:$ koefisien regresi

$X$ : kecemasan matematika

\section{HASIL DAN PEMBAHASAN}

Uji statistik regeresi linear sederhana dilakukan untuk mengetahui pengaruh kecemasan matematika peserta didik terhadap kemampuan pemahaman matematis. Data yang digunakan adalah skor postes kemampuan pemahaman matematis dan skor kecemasan matematika setelah dilakukan pembelajaran pada peserta didik. Sebelum dilakukan uji statistik regresi linear, perlu dilakukan uji asumsi linear klasik.

\section{a. Uji Asumsi Linear Klasik}

\section{1) Uji Normalitas}

Berdasarkan analisis sebelumnya, telah diketahui bahwa data skor postes kemampuan pemahaman matematis dan kecemasan matematika siswa berdistribusi normal.

Tabel 1. Hasil Uji Normalitas

\begin{tabular}{|l|c|c|c|c|}
\hline \multirow{2}{*}{} & \multicolumn{3}{|c|}{ One-sample $K-S$} & \multirow{2}{*}{ Kesimpulan } \\
\cline { 2 - 4 } & Stat & Df & Sig. & \\
\hline Pemahaman Matematis & 0,656 & 66 & 0,782 & Data Berdistribusi Normal \\
\hline Kecemasan Matematika & 0,889 & 66 & 0,408 & Data Berdistribusi Normal \\
\hline
\end{tabular}

\section{2) Uji Linearitas}

Hasil uji linearitas dengan taraf signifikansi $\alpha=0,05$ dan hasilnya disajikan pada tabel berikut:

Tabel 2. Hasil Uji Linearitas

\begin{tabular}{|l|c|c|}
\hline \multirow{2}{*}{} & \multicolumn{2}{|c|}{ Kemampuan } \\
& Pemahaman Matematis \\
\cline { 2 - 3 } & $\mathrm{F}$ & Sig. \\
\hline Kecemasan Matematika & 1,100 & 0,382 \\
\hline
\end{tabular}

Tabel 2 menunjukkan bahwa nilai Sig. $>\alpha$, sehingga $\mathrm{H}_{0}$ diterima. Hal ini menunjukkan bahwa model regresi memenuhi asumsi linearitas.

\section{3) Uji Autokorelasi}

Uji autokorelasi dilakukan menggunakan uji Durbin-Watson pada taraf signifikansi $\alpha=0,05$. Hasilnya disajikan pada tabel berikut:

Tabel 3. Hasil Uji Autokorelasi

\begin{tabular}{|l|c|c|c|}
\hline & Durbin-Watson & DW kritis & Keterangan \\
\hline Kemampuan Pemahaman & 1,671 & $\begin{array}{r}d_{U}=1,629 \\
d_{L}=1,567\end{array}$ & $\mathrm{H}_{0}$ diterima \\
Matematis & & \\
\hline
\end{tabular}

Tabel 3 menunjukkan bahwa nilai $d$ sebesar 1,671 dan berada pada interval $d_{U}<d<\left(4-d_{U}\right)$, sehingga $\mathrm{H}_{0}$ diterima. Hal ini menunjukkan bahwa tidak terdapat autokorelasi.

\section{4) Uji Heterokedastisitas}

Masalah ada atau tidaknya heterokedastisitas dapat dilihat pada scatter plot yang terbentuk. Jika grafik pada scatter plot menunjukkan pola tertentu maka terjadi 
heterokedastisitas. Gambar 1 menunjukkan bahwa scatter plot tidak menunjukkan pola tertentu sehingga dapat disimpulkan bahwa tidak terjadi heterokedastisitas.

Scatterplot

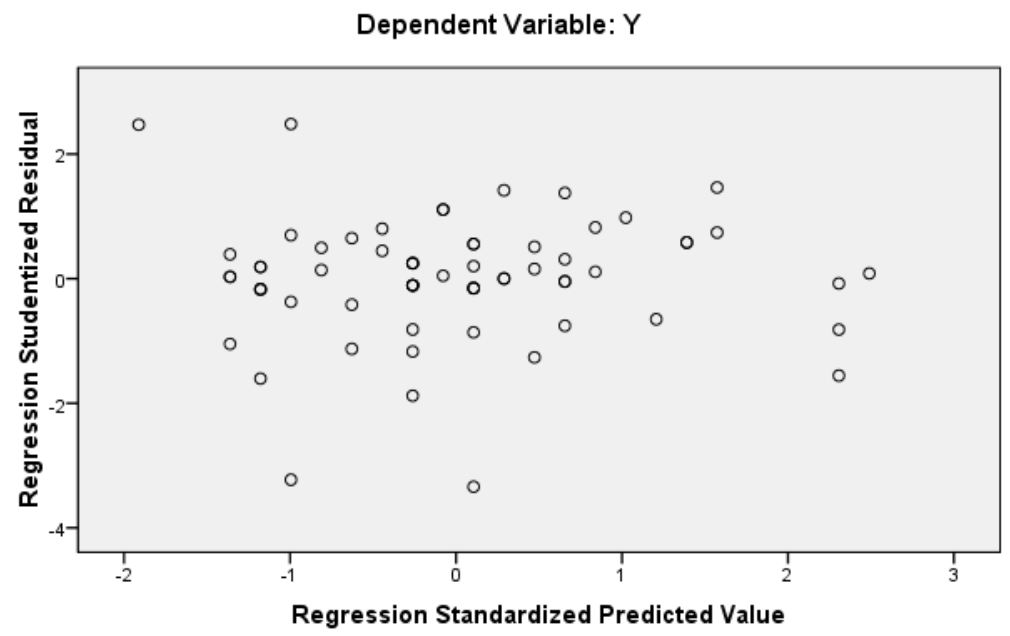

Gambar 1

Scatter Plot untuk Nilai Postes Kemampuan Pemahaman Matematis

\section{b. Uji Kelayakan Model}

Uji kelayakan model regresi dilakukan untuk menunjukkan besarnya persentase kecemasan matematika dalam menjelaskan kemampuan pemahaman matematis dan dapat dilihat dari besarnya koefisien determinasi $\left(\mathrm{R}^{2}\right)$ yang diperoleh. Hasil perhitungan koefisien determinasi disajikan pada tabel berikut:

Tabel 4. Hasil Perhitungan Koefisien Determinasi $\left(\mathrm{R}^{2}\right)$

\begin{tabular}{|c|c|}
\hline & $\begin{array}{c}\text { Kemampuan } \\
\text { Pemahaman Matematis }\end{array}$ \\
\hline Koefisien determinasi & 0,543 \\
\hline
\end{tabular}

Tabel 4 menunjukkan bahwa besarnya koefisien determinasi, yaitu 0,543 atau $54,3 \%$. Hal ini menyatakan bahwa besarnya pengaruh kecemasan matematika terhadap kemampuan pemahaman matematis adalah sebesar 54,3\%, sedangkan sisanya, yaitu sebesar 45,7\% dipengaruhi oleh faktor lain.

\section{c. Pengujian Parameter Regresi}

Perhitungan analisis regresi linear antara kecemasan matematika terhadap kemampuan pemahaman matematis menghasilkan model matematis dari regresi linear sebagai berikut:

$$
\widehat{Y}=35,242-0,565 X
$$

Nilai 35,242 merupakan nilai konstanta yang menunjukkan bahwa jika tidak ada kecemasan matematika maka pemahaman matematis akan mencapai 35,242. Koefisien regresi $\mathrm{X}$ sebesar $-0,565$ menyatakan bahwa setiap ada penambahan satu nilai untuk kecemasan matematika akan menurunkan kemampuan pemahaman matematis sebesar 0,565 . 
Keberartian persamaan regresi yang diperoleh dapat diuji dengan menggunakan uji F. Akan tetapi, karena hanya satu variabel bebas yang digunakan, yaitu kecemasan matematika maka untuk menguji keberartian tersebut juga dapat digunakan uji t. Adapun hipotesis yang diuji adalah:

$\mathrm{H}_{0}$ : Kecemasan matematika tidak berpengaruh signifikan terhadap kemampuan pemahaman matematis.

$\mathrm{H}_{0}$ : Kecemasan matematika berpengaruh signifikan terhadap kemampuan pemahaman matematis.

Hasil perhitungan uji $\mathrm{t}$ dan uji $\mathrm{F}$ pada taraf signifikansi $\alpha=0,05$ selengkapnya dapat dilihat pada table berikut:

Tabel 5. Hasil Uji t dan Uji F

\begin{tabular}{|c|c|c|c|}
\hline Uji Statistik & Nilai hitung & Sig. & Keterangan \\
\cline { 1 - 3 } Uji t & $-8,723$ & 0,000 & \multirow{2}{*}{$\mathrm{H}_{0}$ ditolak } \\
\hline Uji F & 76,093 & 0,000 & \\
\hline
\end{tabular}

Hasil uji statistik $\mathrm{t}$ dan $\mathrm{F}$ pada Tabel 5, menyatakan bahwa nilai signifikansi kedua uji tersebut, yaitu 0,000. Karena nilai Sig. $<\alpha$ maka $\mathrm{H}_{0}$ ditolak, hal ini menunjukkan bahwa kecemasan matematika berpengaruh signifikan terhadap kemampuan pemahaman matematis peserta didik.

Hasil pengujian di atas sejalan dengan pendapat yang dikemukakan oleh HellumAlexander (2010), yaitu kecemasan matematika juga berpengaruh terhadap kemampuan matematis, dan termasuk di dalamnya adalah kemampuan pemahaman matematis. Arem (Zakaria, Zain, Ahmad, dan Erlina, 2012) juga menyatakan bahwa peserta didik dengan kecemasan matematika yang tinggi cenderung kurang percaya diri dalam memahami konsep matematis. Oleh karena itu, kecemasan matematika harus diatasi agar kemampuan pemahaman matematis dapat berkembang dengan lebih baik.

\section{PENUTUP}

\section{Simpulan}

Kecemasan matematika berpengaruh signifikan terhadap kemampuan pemahaman matematis peserta didik. Hal tersebut dibuktikan oleh hasil uji statistik $\mathrm{t}$ dan F, menyatakan bahwa nilai signifikansi kedua uji tersebut, yaitu 0,000. Karena nilai Sig. $<\alpha$ maka $\mathrm{H}_{0}$ ditolak, dengan model matematis regresi linear sebagai berikut: $\hat{Y}=$ $35,242-0,565 X$. Nilai 35,242 merupakan nilai konstanta yang menunjukkan bahwa jika tidak ada kecemasan matematika maka pemahaman matematis akan mencapai 35,242. Koefisien regresi X sebesar - 0,565 menyatakan bahwa setiap ada penambahan satu nilai untuk kecemasan matematika akan menurunkan kemampuan pemahaman matematis sebesar 0,565 .

\section{Saran}

1. Guru harus mampu menciptakan lingkungan pembelajaran yang positif, yang bebas dari ketegangan dan memungkinkan timbulnya perasaan malu atau terhina.

2. Pembelajaran yang dilakukan sebaiknya tidak hanya fokus pada keterampilan berhitung seperti penjumlahan, pengurangan, perkalian dan pembagian sejumlah bilangan. Akan tetapi, pemahaman konsep yang baik membutuhkan komitmen peserta didik dalam memilih belajar sebagai suatu yang bermakna, lebih dari hanya menghafal, yaitu membutuhkan kemampuan peserta didik untuk mencari hubungan konseptual antara pengetahuan yang dimiliki dengan yang sedang dipelajari di dalam kelas. 


\section{DAFTAR PUSTAKA}

Alamijaya, J. Siswa Cemas Soal Matematika. (17 April 2012). Tribun News. [Online]. Tersedia: m.yahoo.com/w/legobpengine/news/siswa-cemas-soal-matematika08251509.html?orig_host_hdr=id.berita.yahoo.com\&.intl=ID \&.lang=id-ID. [15 Desember 2012].

Badudu, A. 1.330 Siswa SMP Tak Lulus UN Matematika. (3 Juni 2012). Tempo. [Online]. Tersedia: m.tempo.co/read/news/2012/06/03/079408015/1330-SiswaSMP-Tak-Lulus-UN-Matematika. [15 Desember 2012].

BSNP. 2006. Standar Kompetensi dan Kompetensi Dasar SMP/MTs. Jakarta: Balitbang.

Cheung, K. C. 2012. Conceptualization of The PISA Mathematical Literacy Proficiency Scale: A Validation of Its Cognitive Components. Disajikan pada The East Asia Forum on Mathematics Competence and Their Assessment, 10-11 Mei 2012, East China Normal University, Shanghai.

Daneshamooz, S., Alamolhodaei, H. \& Darvishian, S. 2012. Experimental research about effect of mathematics anxiety, working memory capacity on students' mathematical performance with three different types of learning methods. ARPN Journal of Science and Technology Vol. 2, No. 4.

Erdoğan, A., Kesici, Ş,. Şahin, İ. 2011. Prediction of high school students' mathematics anxiety by their achievement motivation and social comparison. Elementary Education Online, 10(2), 646-652.

Freeman. 2006. Mathematical Anxiety. [Online]. Tersedia: http://en.wikipedia.org/wiki/mathematicalAnxiety.

Gresham, G. 2010. A study exploring exceptional education pre-service teachers' mathematics anxiety. IUMPST: The Journal Vol. 4.

Hellum-Alexander, A. 2010. Effective Teaching Strategies for Alleviating Math Anxiety and Increasing Self-Efficacy in Secondary School. A Thesis submitted in partial fulfillment of the requirements for the degree Master in Teaching, The Evergreen State College.

Hiebert, J., Carpenter, T. P. 1992. Learning and Teaching with Understanding. Dalam D. A. Grows (Ed.), Handbook of Research on Mathematics Teaching and Learning. New York: Macmillan Publishing Company.

Kastberg, S. E. 2002. Understanding Mathematical Concepts: The Case of The Logarithmic Function. Disertasi Doktor Universitas Georgia. Georgia.

Luo, X., Wang, F. \& Luo, Z. 2009. Investigation and analysis of mathematics anxiety in middle school students. Journal of Mathematics Education Vol. 2, No. 2, pp. 12-19.

Mainey, F. 2004. Teaching Techniques in Overcoming Mathematics Anxiety. [Online]. Tersedia: $\quad$ http://mathculator.com/Downloads/Files/Papers\% 20and\%20articles/Teaching\%20Techniques\%20in\%200vercoming\%20Mathema tics\%20Anxiety.doc [23 September 2012].

Meel, D. E. 2003. Models and theories of mathematical understanding: comparing pirie and kieren's models of the growth of mathematical understanding and apos theory. Journal of CBMS Issues in Mathematics Education, vol. 12.

Mullis, I. V. S., Martin, M.O., Foy P., Arora, A. 2012. TIMSS 2011 International Result in Mathematics. Netherlands: IEA.

NCTM. 2000. Principles and Standards for School Mathematics. Reston, VA: The National Council of Teachers of Mathematics, Inc.

Nurhanurawati, Sutiarso S. 2008. Mengatasi kecemasan (anxiety) dalam pembelajaran matematika. JPMIPA, Vol. 9 No. 1, Januari 2008. 
Rupilu, N. Waspadai Kecemasan Matematika pada Anak. (20 November 2012). Kompasiana. [Online]. Tersedia: m.kompasiana.com/post/edukasi/2012/ 11/20/waspadai-kecemasan-matematika-pada-anak. [15 Desember 2012].

Ruseffendi, E. T. 1991. Penilaian Pendidikan dan Hasil Belajar Siswa Khususnya dalam Pengajaran Matematika untuk Guru dan Calon Guru. Bandung: Diktat.

Sheffield, D., Hunt, T. 2006. How does anxiety influence maths performance and what can we do about it?. MSOR Connections Vol. 6 No. 4.

Skemp, R. R. 1976. Relational understanding and instrumental understanding. Mathematics Teaching, 77, 20-26.

Smith, M. R. 2004. Math Anxiety: Causes, Effects, and Preventative Measures. A Senior Thesis submitted in partial fulfillment of the requirements for graduation in the Honors Program, Liberti University.

Sun, Y., Pyzdrowski, L. 2009. Using technology as a tool to reduce mathematics anxiety. The Journal of Human Resource and Adult Learning Vol. 5, Num. 2.

Utomo, D. P. 2010. Pengetahuan Konseptual dan Prosedural dalam Pembelajaran Matematika. Makalah pada Seminar Nasional Matematika dan Pendidikan Matematika Universitas Muhammadiyah Malang.

Vahedi, S., Farrokhi, F. 2011. A confirmatory factor analysis of the structure of abbreviated math anxiety scale. Iran Journal Psychiatry, 6, 47-53.

Warren Jr, W.H., Rambow, A., Pascarella, J., Michel, K., Schultz, C. \& Marcus, S. 2005. Identifying and Reducing Math Anxiety. CTLA 704 Workshop.

Zakaria, E., Zain, N. M., Ahmad, N. A., \& Erlina, A. 2012. Mathematics anxiety and achievement among secondary school students. American Journal of Applied Sciences, 9 (11), 1828-1832.

Zakaria, E., Nordin, N.M. 2007. The effects of mathematics anxiety on matriculation students as related to motivation and achievement. Eurasia Journal of Mathematics, Science \& Technology Education, 2008, 4(1), 27-30. 